\title{
Land use change detection in Denizli City Center using spectral angle mapper method and evaluations in terms of some earth science data
}

\section{Spektral açı haritalama yöntemi ile Denizli Kent Merkezi arazi kullanım değişim tespiti ve bazı yerbilim verileri açısından değerlendirilmesi}

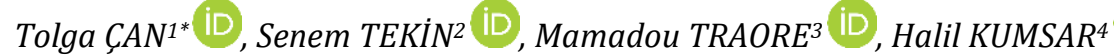 \\ ${ }^{1,3}$ Geological Engineering Department, Engineering Faculty, Cukurova University, Adana, Turkey. \\ tolgacan@cukurova.edu.tr, matraba77@gmail.com \\ 2Mining and Mineral Extraction Department, Adıyaman University, Adıyaman, Turkey. \\ senemtekin@adiyaman.edu.tr \\ ${ }^{4}$ Geological Engineering Department, Engineering Faculty, Pamukkale University, Denizli, Turkey \\ kumsarh@gmail.com
}

\begin{abstract}
Land use planning is central for a sustainable development processes and should be structured in harmony with geo-environmental constrains. In this study, land use change detection was determined in Denizli residential area between the years 1984 and 2018. In the analyses, Landsat-5TM and Landsat-8 OLI images were used for 1984 and 2018, respectively. The geometric, radiometric calibration and atmospheric corrections were applied to the satellite images in preprocessing stage. Land use change detection was performed using supervised classification -Spectral Angle Mapper-method. Accuracy of the classifications was evaluated by the kappa index, which was 0.80 for 1984 and 0.87 for 2018 image. According to the results, between 1984 and 2018 there was an increase of $155 \%$ and $96 \%$ in built up and forest areas, while $52 \%$ and $40 \%$ decrease were observed in agriculture and bare land, respectively. It was also determined that the majority of the settlement areas increased in regions close to active fault zones. Accordingly, the built up areas within the $500 \mathrm{~m}$ buffer zone to the active faults were increased by 240\% from 1984 to 2018.
\end{abstract}

Keywords: Land use, Change detection, Remote sensing, Landsat, Denizli

\section{Introduction}

The exponential growth of the human population in the past two hundred years has led to significant changes in natural and built environments. Although urbanization is regarded as a positive process related to population growth, industrialization, and global integration, it is economically benefited only by the minority of the urban population [1]. Land use change is a complex and dynamic processes associated with the political, economic, cultural, technological and natural driving forces and the respective factors [2],[3]. The last spatial planning construction regulation came into force in 2014 in Turkey. The aim of the regulation is to protect and develop physical, natural, historical and cultural values, to ensure the balance of protection and use, to support sustainable development at the country, region and city level, to create healthy and safe environments with high quality of life. In the

\section{Öz}

Arazi kullanım planlaması, sürdürülebilir kalkınma süreclerinin merkezinde yer almakta olup, jeo-çevresel șartlara uyumlu bir șekilde yapılandırılmalıdır. Bu çalışmada, Denizli kent merkezinde 1984 ve 2018 yılları arasında arazi kullanımında meydana gelen değișimler belirlenmiştir. Analizlerde, 1984 ve 2018 yılları için sırasıly Landsat-5 TM ve Landsat-8 OLI görüntüleri kullanılmıștır. Uydu görüntülerinde ön ișlem așamasında geometrik, radyometrik kalibrasyon ve atmosferik düzeltmeler uygulanmıştır. Arazi kullanımı değişim tespiti, kontrollü sinıflandırmalardan, Spektral Aç Haritalama yöntemi kullanılarak gerçekleştirilmiștir. Sınıflandırmanın doğruluğu kappa indeksi ile değerlendirilmiș olup 1984 yılı için 0.80, 2018 yılı için 0.87 olarak bulunmuştur. Elde edilen sonuçlara göre 1984 ile 2018 yılları arasında yerleșim ve orman alanlarında sırasıyla \%155 ve \%96'lık artış meydana gelirken, tarım ve ciplak arazilerde ise \%52 ve \%40'lık oranlar da azalma gözlenmiştir. Yerleşim alanlarının büyük çoğunluğunun, aktif fay zonlarına yakın bölgelerde arttığı belirlenmiștir. Buna göre, çalıșma alanında yer alan aktiffaylara 500 m'lik zonlar içerisinde, 1984 ile 2018 yılları arasında yapılaşma alanlarındaki artış, \%240 olarak tespit edilmiştir.

Anahtar kelimeler: Arazi kullanımı, Değișim tespiti, Uzaktan algılama, Landsat, Denizli.

regulation, the planning stages, from the upper level to the lower level are represented by Spatial Strategy Plan, Environmental Plan, Master development, and Implementation development Plan. In all plans, among others, the natural disaster and geological data is included in the general planning principles. In spatial strategy planning covering the national and regional level and in the environmental plans made at the region, basin or province level, it is necessary to analyze and identify natural hazards and risks for reducing the losses and take measures to decrease disaster risks. In master development and implementation development plans, geological-geotechnical or micro-zoning studies, geological, geomorphological, hydrological and hydrogeological structure, potential hazards of natural disasters, settlement suitability, risk management and mitigation plans should also be evaluated. 
Denizli is one of the most important cities of the Aegean region in terms of geothermal energy, marble, agriculture, tourism textile and other industrial capacity. Denizli city, which was founded under the name of Laodikeia in the third century BC, has been severely suffered from major earthquakes that caused loss of life and property [4]. The city center and its surroundings are surrounded by Denizli and Babadağ fault zones [5], so it has high seismic activity today as it was in history. It is known that many ancient cities in and around Denizli were destroyed as a result of historical earthquakes [6]. Land use planning is a systematic procedure in order to create more desirable social and environmental conditions also reducing risks from natural hazards. In the early 2000s, geological, geotechnical and hydrogeological investigations in Denizli Municipality urban settlement area were carried out by Pamukkale University [7] and a geological-geotechnical urban information system for Denizli [8]-[10] was first time developed by GEOUKS computer program written by [11] in $\mathrm{C}^{++}$ programming language. However, the urbanization has extended rapidly to the western part of the Municipality after the settlement suitability map of Denizli was first published by [7]. In this study land use change processes were carried out in the region of $206 \mathrm{~km}^{2}$, covering the central district of Denizli (Figure 1). It has identified that urbanization has extended mainly on agriculture and bare lands without taking into consideration of active fault zones.

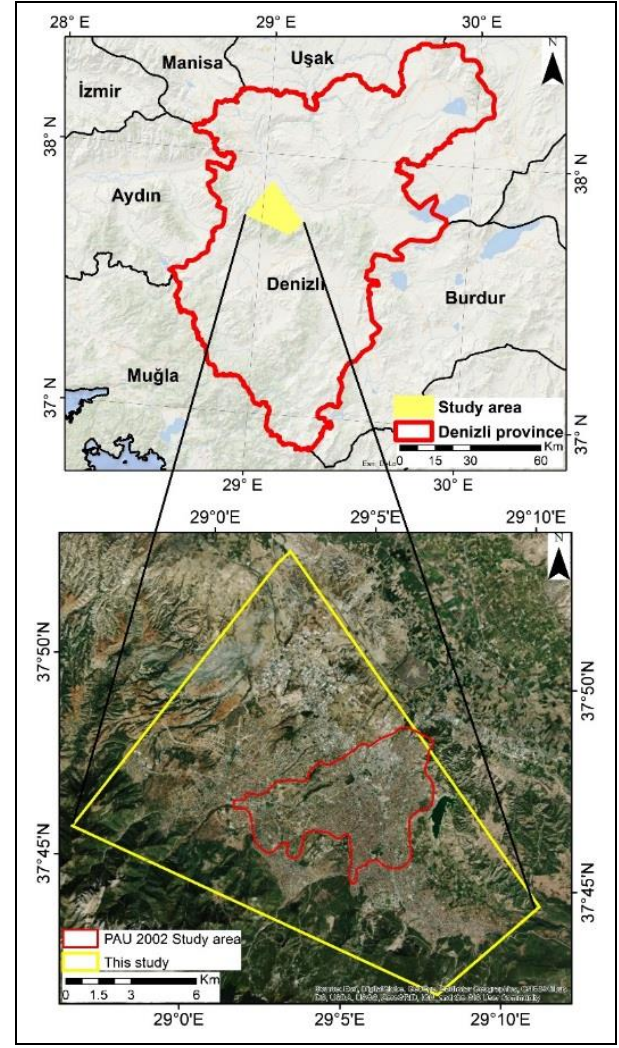

Figure 1. Location map of the study area.

\section{Geological and morphological settings}

The study area is geologically located in Denizli basin/graben. The oldest geological units exposed in the area are Paleozoic schist-quarzites (Ortaköy formation) and marbles (Paşapınar formation) of the Menderes massif. The Tavas nappe, the lowermost unit of Lycian nappes, overlie the Menderes massif units with Jurassic-Cretaceous limestones and calciturbidites (Babadağ formation) [12] followed by mainly Upper Paleocene to Eocene limestones and clastics (Faralya formation) [17],[13]. The Neogene cover units in the study area is represented by Kolonkaya formation of Late Miocene- Pliocene consisting of limestones and clastic sediments [14]. Quaternary deposits are mainly represented by lake, coastal plain, floodplain, terrace and alluvial fan deposits. Pre Neogene units are located within footwall whereas Neogene-Quaternary units are located within the hanging wall of the Denizli and Babadag fault zones of the Denizli Graben [15] (Figure 2).

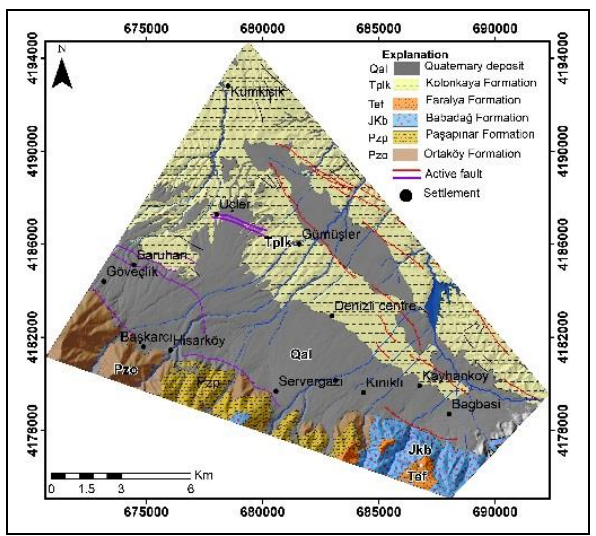

Figure 2. The active faults [5] and simplified geological map [12], [16] of the study area.

The $35 \mathrm{~km}$ long Babadağ fault zone is located in the southwestern parts of the study area, with Quaternary activity, Generally, it trends at $\mathrm{N} 60^{\circ} \mathrm{E}$, and dips $55-70^{\circ}$ to northeast. The $25 \mathrm{~km}$ long Denizli fault zone, trending $\mathrm{N} 45^{\circ} \mathrm{W}$ and dipping 55$70^{\circ}$ to northeast, is located in the central parts of the study area with Holocene activity [5]. Figure 3 represents the historical and instrumental earthquakes recorded around the region. It is known that the city center and villages caused by strong earthquakes occurred in magnitude of 6.6 in 1702 and 6.5 in 1717 were damaged, almost the city was rebuilt and nearly 6,000 loss of life were recorded by the earthquakes [6].

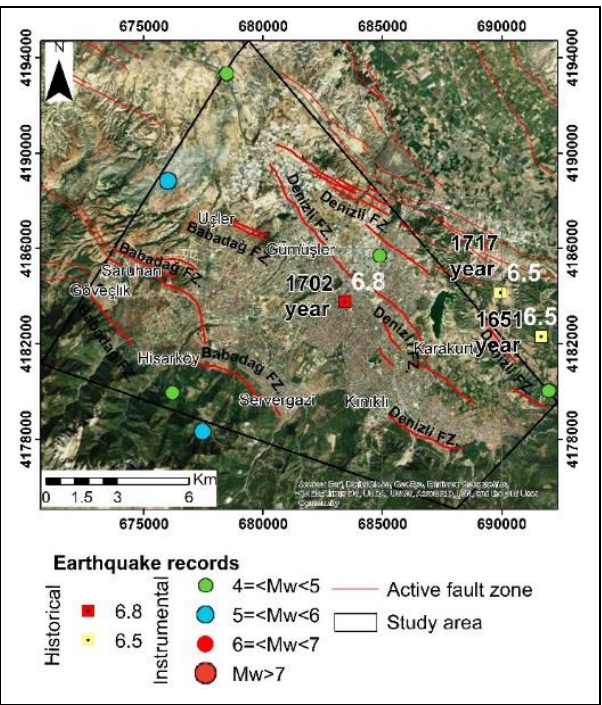

Figure 3. Spatial distribution of Active faults in the study area [4], Historical earthquake record [17], and Instrumental earthquake records of the study area and its vicinity [18]. 
The elevation ranges between 166 and $2288 \mathrm{~m}$ and is gradually decreasing from south to north (Figure 4). The southern parts of the study area where basements units exposed through the Babadağ and Honaz mountains is represented by steep slopes up to 67 degrees. The slopes of less than 10 degrees corresponding $62 \%$ of the study area located around the Denizli city center and its surroundings (Figure 5).

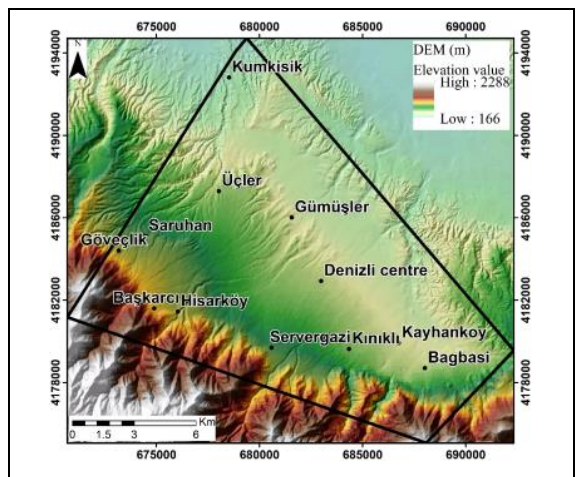

Figure 4. Digital elevation model of the study area.

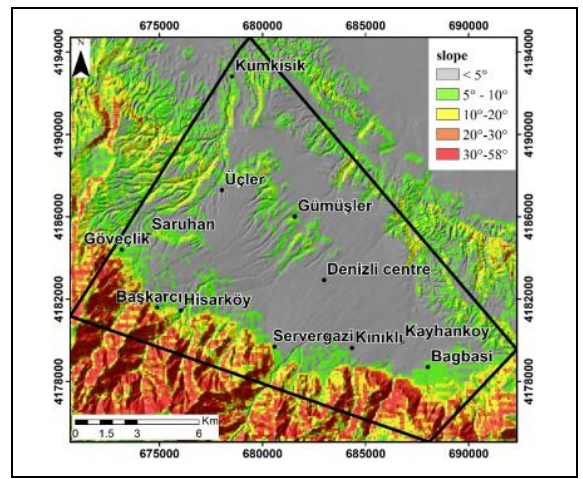

Figure 5. Slope map of the study area.

\section{Method}

Land use change is mainly based on the comparison of the state of features, using at least two images that are taken at different times. In preprocessing stage, firstly, geometrical distortions between the two images are harmonized with each other using certain control points. Secondly, radiometric corrections were carried out in order to eliminate the atmospheric effects causing irregular and false sensations in the images and to correct the reflections that did not fully represent objects from the radiation detected by the sensors. Then, atmospheric correction and image enhancement processes were performed to eliminate the spectral effect of water vapor and aerosols.

Spectral Angle Mapper (SAM) method was used for change detection. SAM is a supervised classification based spectral of band that uses an angle to match pixels to reference spectra (training sets). The algorithm assigns the spectral similarity between two spectra by calculating the angle between the spectra and treating them as vectors in a space with dimensionality equal to the number of bands [19] (Figure 6).

Small angles between the two spectrums indicate high similarity and vice versa. Repressing the influence of shading effects to accentuate the target reflectance characteristics is another advantage of the method [20]. This technique functions well in the face of scaling noise. The mathematical formulation of SAM was given by equation 1 :

$$
=\cos ^{-1} \frac{\sum X Y}{\sqrt{\sum X^{2} \sum Y^{2}}}
$$

Where:

$\alpha \quad$ : Angle formed between reference spectrum and image spectrum

$\mathrm{X} \quad$ : Image spectrum

Y : Reference spectrum

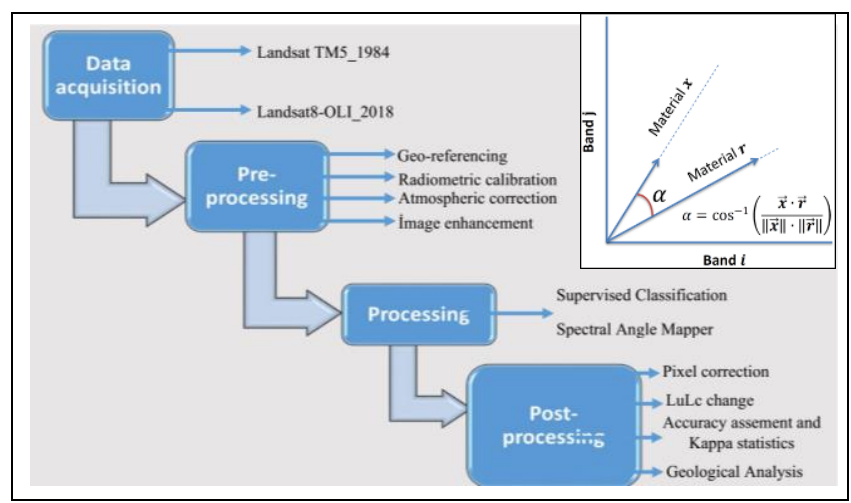

Figure 6. The stages of the methods applied in this study.

\section{Results}

Denizli city center is growing fast due to rapid population growth and migration from rural areas. In this study, land use changes in Denizli city center were determined using remote sensing techniques and Landsat satellite images between 1984 and 2018. Four land use classes namely, agricultural areas, forest, settlement, and bare lands were used in the classification made on the image dated 1984. In the classification for 2018, in addition to 1984, the water body class was also included. Land use classes for 1984 and 2018 are given in Figure 7.

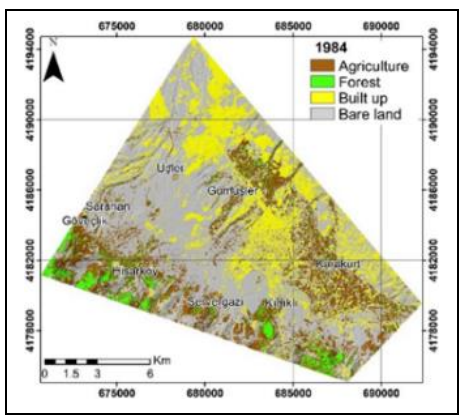

(a)

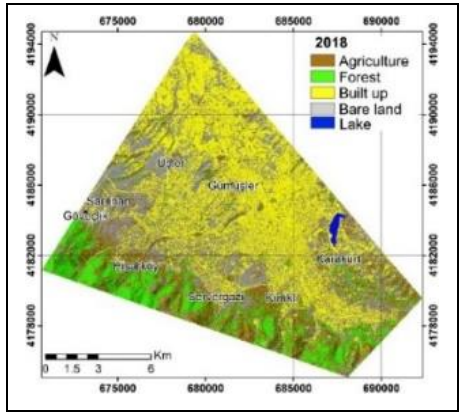

(b)

Figure 7. Land use classification map for 1984 (a), 2018 (b). 
Performance evaluation of classifications was made using confusion matrix for general accuracy, and statistical differences between classifications using Kappa coefficient. Kappa statistics is a measurement mechanism between reference data and user-defined classified data [21],[22]. When the classification error matrices are examined, the total Kappa value of the classes is determined as 0.80 for 1984 and 0.87 for 2018 (Table 1).

Table 1 . The results of the accuracy assessment and the kappa statistics.

\begin{tabular}{|c|c|c|c|c|}
\hline \multirow{3}{*}{$\begin{array}{l}\text { Class } \\
\text { Names }\end{array}$} & \multicolumn{2}{|c|}{1984} & \multicolumn{2}{|c|}{2018} \\
\hline & Producer's & User's & Producer's & User's \\
\hline & Accuracy & Accuracy & Accuracy & Accuracy \\
\hline Unclassified & 0 & 0 & 0 & 0 \\
\hline Agriculture & 92.86 & 86.67 & 84.62 & 91.67 \\
\hline Forest & 81.25 & 86.67 & 91.67 & 91.67 \\
\hline Built Up & 81.25 & 86.67 & 83.33 & 83.33 \\
\hline Water & & & 100.00 & 100.00 \\
\hline \multirow{3}{*}{$\begin{array}{c}\text { Bare soil/Rock } \\
\text { Accuracy } \\
\text { Kappa }\end{array}$} & 85.71 & 80.00 & 90.91 & 83.33 \\
\hline & \multicolumn{2}{|c|}{$\% 85.00$} & \multicolumn{2}{|c|}{$\% 90.00$} \\
\hline & \multicolumn{2}{|c|}{0.8000} & \multicolumn{2}{|c|}{0.8750} \\
\hline
\end{tabular}

Accordingly, it was determined that the highest classes in the study area consisted of bare lands in 1984 and 2018 with $64.15 \%$ and $38.69 \%$, respectively (Figure 8). On the relevant dates, it was determined that there was a decrease in agriculture and bare areas from land change classes, while an increase occurred in forest and built up areas (Figure 9).

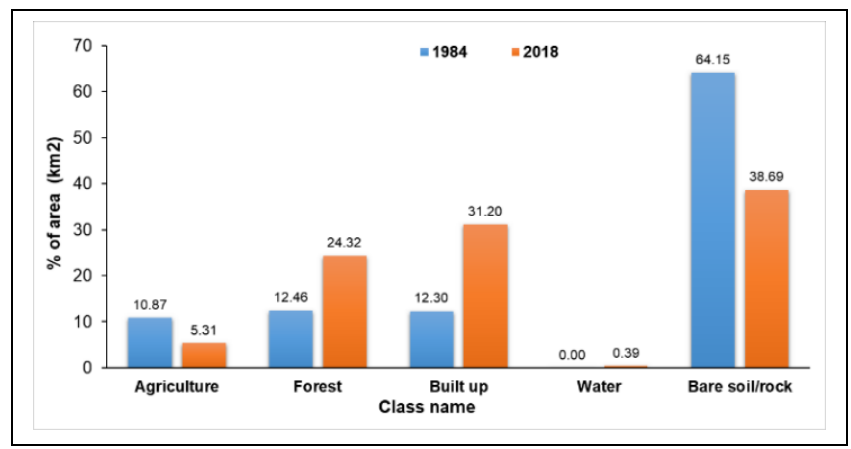

Figure 8. Distribution of land use class percentages for 1984 and 2018.

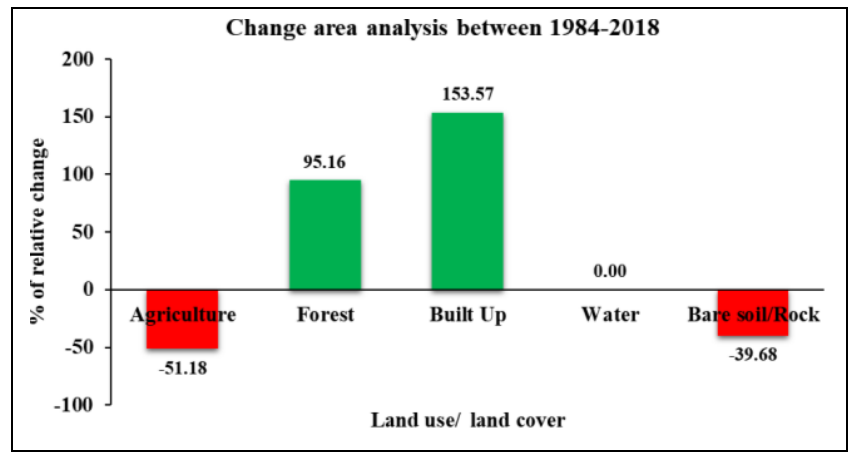

Figure 9. Overall land use changes between 1984-2018.

It has been determined that $36 \%$ of the settlements are located on the Quaternary units, which are sensitive to seismic hazards. In addition, the built up areas in $500 \mathrm{~m}$ buffer zones around the active faults has increased $240 \%$ between 1984 and 2018 (Figure 10).

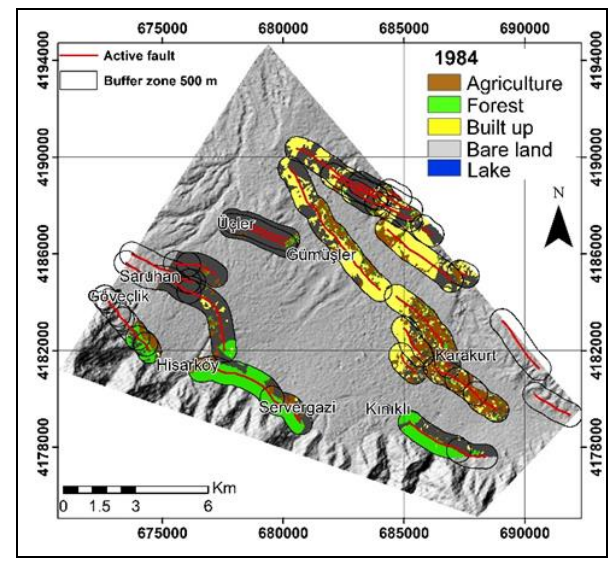

(a)

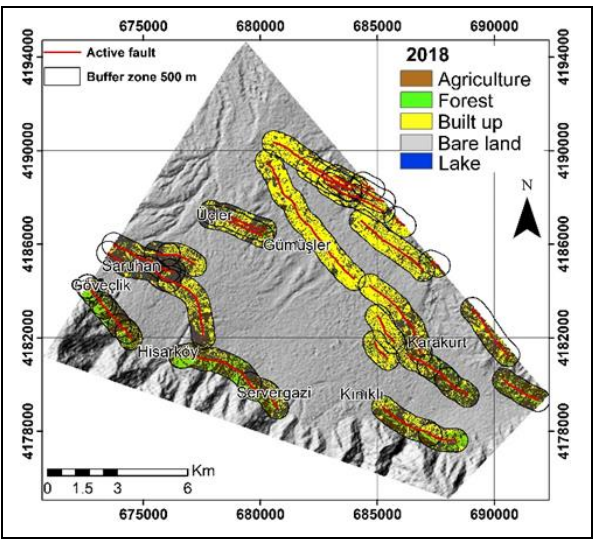

(b)

Figure 10. Changes in regions close to active fault lines for 1984 (a) and 2018 (b).

\section{Conclusions}

Denizli city is one of the leading cities in Turkey in terms of agriculture, industry, culture and tourism. The city is located in seismically high hazard zone. According to the results obtained, an increase of $153.57 \%$ was observed in built up areas between 1984 and 2018. It has been also determined that most of the settlements are located on the Quaternary units and around the active fault zones, which are geologically sensitive to strong ground shaking, liquefaction and other ground deformations. Turkey earthquake hazard maps and earthquake building regulations came into force on 1 January 2019. In order to eliminate the adverse effects of possible earthquake hazards on urbanized areas, effective land use planning strategies should be evaluate in large scales with detailed micro zonation studies considering site specific geological, seismological and geotechnical characteristics.

\section{References}

[1] Bhatta B. "Analysis of urban growth pattern using remote sensing and GIS: a case study of Kolkata, India". International Journal of Remote Sensing, 30(18), 4733-4746, 2009. 
[2] Turner BL, Clark WC, Kates RW, Richards JF, Mathews JT, Meyer WB. The earth as transformed by human action: global and regional changes in the biosphere over the past 300 years. Editors: Turner,BL, Massachusetts William C, Massachusetts Robert W, Island, R, Richards, F, William DC, Meyer B. Global and Regional Changes in the Biosphere over the Past 300 Years, Cambridge University, Environment and Society Graduate School of Geography and George Perkins Marsh Institute Press, ISBN-13, 9780521446303, 1990.

[3] Hersperger AM, Oliveira E, Pagliarin S, Palka G, Verburg P, Bolliger J, Grădinaru S. "Urban land-use change: The role of strategic spatial planning". Global Environmental Change, 51(2018), 32-42, 2018.

[4] Uluskan, M. "Osmanlı kaynaklarına göre 1703 ve 1717 denizli depremleri". Uluslararası Denizli ve Çevresi Tarih ve Kültür Sempozyumu 1, Denizli, Türkiye, 6-8 Eylül 2006.

[5] Emre Ö, Duman TY, Özalp S, Elmacı H. “1:250.000 Ölçekli Türkiye Diri Fay Haritası Serisi, Denizli (NJ 35-12) Paftası". Maden Tetkik ve Arama Genel Müdürlüğü, Ankara, Türkiye, 12, 2011.

[6] Kumsar H, Aydan Ö, Şimşek C, D’Andria F. "Historical earthquakes that damaged Hierapolis and Laodikeia antique cities and their implications for earthquake potential of Denizli basin in Western Turkey". Bulletin of Engineering Geology and the Environment, 75, 519-536, 2016.

[7] Pamukkale Üniversitesi. "Denizli Belediyesi Mücavir Alanının Jeolojik, Jeoteknik ve Hidrojeolojik Açıdan İncelenmesi Raporu”. Denizli, Türkiye, 763, 2002.

[8] Çelik SB. Denizli il Merkezi Zeminlerinin Jeolojik, Jeoteknik Açıdan İncelenmesi ve Sıvılaşma Duyarlılı̆̆ının Belirlenmesi. Pamukkale Üniversitesi, Yüksek Lisans Tezi, Denizli, Türkiye, 2003.

[9] Kumsar H, Çelik SB, Kaya M. "Denizli il merkezi yerleşim alanının jeolojik, jeoteknik kent bilgi sistemi (JEO-KBS)”. Pamukkale Üniversitesi, Mühendislik Bilimleri Dergisi, 10(4), 25-31, 2004.

[10] Kumsar H, Çelik SB, Kaya M, Topaloğlu S. "Geologicalgeotechnical urban information system for Denizli". Mühendislik Jeolojisi Bülteni-Bulletin of Engineering Geology, (21), 35-47, 2005.

[11] Kumsar, H. Mine Slope Stability Assessment by Using InerSlice Force Transmission Theory. PhD Thesis, Nottingham University, Nottingham, United Kingdom of Great Britain and Northern Ireland, 1993.
[12] Konak N, Hepșen N, Öztürk EM, Öztürk Z, Çakmakoğlu A, Göktaş F, Sarıkaya H, Armağan F, Çatal E, Serdaroğlu M. "Menderes masifi'nin G-GD'sundaki mesozoyik istiflerin karşılaştırılmalı stratigrafisi ve konumları". Türkiye Jeoloji Kurultayı, Ankara, Türkiye, 16-20 Şubat 1987.

[13] Şenel M, Akdeniz N, Öztürk EM, Özdemir T, Kadınkız G, Yüksel M, Öcal H, Serdaroğlu M, Örçen S. "Fethiye (Muğla) Kalkan (Antalya) ve kuzeyinin jeolojisi”. Maden Tetkik ve Arama Genel Müdürlüğü, Ankara, Türkiye, 9761, 1994. (unpublished).

[14] Alçiçek H, Varol B, Özkul M. "Sedimentary facies, depositional environments and palaeogeographic evolution of the neogene Denizli Basin, SW Anatolia Turkey". Sedimentary Geology, 202(4), 596-637, 2007

[15] Özpınar Y, Hançer M, Semiz B. "Clays in Denizli region (Southwestern Anatolia), Turkey". Geologica Carpathica, 53(2), 109-116, 2002.

[16] Konak N, Şenel M. “Geological map of Turkey in 1/500.000 scale: Denizli sheet". Mineral Research and Exploration Directorate of Turkey (MTA), Ankara, Turkey, 2002.

[17] Başarır Baştürk N, Özel NM, Altınok Y, Duman, TY. "Türkiye ve Yakın Çevresi için Geliştirilmiş Tarihsel Dönem (MÖ 2000 - MS 1900) Deprem Katalogu". Editör: Duman TY. Türkiye Sismotektonik Haritası Açılama Kitabı, 111-146 MTA Özel Yayınlar Serisi-35, Ankara, Türkiye, 2016.

[18] T.C. "Afet Acil Durum Yönetimi Başkanlığı". https://deprem.afad.gov.tr/ (02.04.2020).

[19] Kruse FA, Lefkoff AB, Dietz JB. "Expert system-based mineral mapping in northern Death Valley, California/Nevada using the Airborne Visible/Infrared Imaging Spectrometer (AVIRIS)". Remote Sensing of Environment, 44(2-3), 309-336, 1993.

[20] DE Carvalho JO, Meneses P. "Spectral correlation mapper (SCM): An improvement on the spectral angle mapper (SAM)". Summaries of the $9^{\text {th }}$ JPL Airborne Earth Science Workshop,Chicago, US, 23-25 February, 2000.

[21] Cohen J. "A coefficient of agreement for nominal scales". Educational and Psychological Measurement, 20, 37-46, 1960.

[22] Landis JR, Koch GG. "The measurement of observer agreement for categorical data". International Biometric Society, 33(1), 159-174, 1977. 